\title{
Organizational Politics, Turnover Intention and Organizational Commitment as Predictors of Employees' Efficiency and Effectiveness in Academia
}

\author{
Lasun Gbadamosi \\ Department of Educational \\ Foundation \& Management, \\ Olabisi Onabanjo University, \\ Ago-iwoye, Ogun State, Nigeria
}

lasungbadamosi@yahoo.com
Nwosu Jonathan Chinaka Babcock University Ilishan, Ilishan-Remo, Ogun State, Nigeria

\begin{abstract}
This study examined the prediction of organizational politics, turnover intention and organizational commitment on employees' efficiency and effectiveness in academia. It made use of 200 randomly selected employees of Babcock University Ilishan, Ilishan - Remo, Ogun State, Nigeria. The age range of the respondents was between 25 and 53 years with mean age of 36.1 and standard deviation of 3.01. The expost-facto research design was employed. Three standard instruments: Perception of Organizational Politics Scale (POPS) by Kacmar and Carlson (1994); Organization Commitment Scale by Meyer and Allen (1991); Turnover Intention Scale by O Driscoll and Benhrs (1994) ; respondents' annual performance evaluation report were used in generating data for the study. Data Analysis involved the use of correlation and multiple regressions. The result indicated that the predictor variables combined and separately made significant contribution to the prediction of the criterion variable. Also, high and positive correlations were found between organizational politics and turnover intention, work efficiency and organizational commitment. On the basis of the findings, it was suggested that a happy employee is a better employee.
\end{abstract}

Keywords. Organizational Politics, Organizational Commitment, Turnover Intentions, Employees' Efficiency and Effectiveness

\section{Introduction}

In the world over, human factor (workers) is the most important and highly needed for any or-

Material published as part of this publication, either on-line or in print, is copyrighted by the Informing Science Institute. Permission to make digital or paper copy of part or all of these works for personal or classroom use is granted without fee provided that the copies are not made or distributed for profit or commercial advantage AND that copies 1) bear this notice in full and 2) give the full citation on the first page. It is permissible to abstract these works so long as credit is given. To copy in all other cases or to republish or to post on a server or to redistribute to lists requires specific permission and payment of a fee. Contact Publisher@InformingScience.org to request redistribution permission. ganization to achieved its goals and continue to progress. The extent to which this can be actualized depends primarily / principally if not entirely on the workers. Ogunyemi (2007) submitted that no organization can achieve its objective without adequate and effective workforce. However, in diagnosing organizational problems most especially, low performance or inefficiency is often made first to the employees. Employees 
are indeed a criterion factor in the actualization of organizational goals.

As important as human resources are to the achievement of the organizational goal, it is regrettable to state that as a result of certain factors or reasons in recent time, it has been observed that their attitude towards the organizational goals is averagely low. Thus, inefficiency and unproductivity of workers on the job is a manifestation of some factors not just inherent with the individual employee but also with the totality of the organizational structure.

The need for factor that predicts employees' effectiveness has become more critical to organizational success especially in academia. One of the factors that could lead to overall organizational performance and productivity in the dynamic and competition technology world today is employees' efficiency on their job. Employees' efficiency on their job has emerged as a promising area of research within the study of industrial and labour relations in the recent time (Gbadamosi \& Nwosu, 2010; Meyer \& Allen, 1997; Ogunyemi, 2007; Salami, 2008).

A variety of studies have recently pointed to organizational politics as an important antecedent of employees' performance, both formal and informal (Adams et al., 2002; Ferris \& Kacmar, 1992; Gandz \& Murray, 1980; Kacmar \& Baron, 1999; O'Connor \& Morrison, 2001; Valle \& Perrewe, 2000). Most of these studies, and others, have relied on the definition of organizational politics as behavior strategically designed to maximize self-interests (Ferris et al., 1989 in Vigodata-Gadot, 2006) and therefore in conflict with the collective organizational goals or the interests of other individuals. This perspective reflects a generally negative image of workplace politics in the eyes of most organization members. Although treated as separate constructs, several studies have also related organizational politics to the theory of fairness, equity, and justice in the workplace (Ferris \& Kacmar, 1992, Vigoda-Gadot, 2003). Other studies describe organizational politics as a power game and influence tactics designed to achieve the best outcomes for the user (Kipnis et al., 1980; Pfeffer, 1992).

Studies that developed the concept of organizational politics (Andrews \& Kacmar, 2001; Cropanzano \& Kacmar, 1995; Dipboye \& Foster, 2002; Fedor et al., 1998; Ferris \& Kacmar, 1992; Vigoda-Gadot, 2003) found that workplace politics was perceived as self-serving behavior by employees to achieve self-interests, advantages, and benefits at the expense of others and sometimes contrary to the interests of the entire organization or work unit. This behavior was frequently associated with manipulation, defamation, subversiveness, and illegitimate ways of overusing power to attain one's objectives (Kipnis et al., 1980). Ferris et al. (1989) suggested that the concept of the perception of organizational politics (Perception of Organizational Politics Scale POPS) as a good measure of OP. Moreover, Kacmar and Ferris (1991) and Ferris and Kacmar (1992) argued that the higher the perceptions of politics are in the eyes of an organization member, the lower in that person's eyes is the level of justice, equity, and fairness.

Turnover intentions are the thoughts of the employees regarding voluntary leaving the organization (Whitman, 1999). The intention to quit is probably the most important immediate antecedent of turnover decisions. Turnover intention is used instead of actual turnover because in general the theory of planned behavior (Ajzen, 1991) suggests that behavioural is a good predictor of actual behaviour. In fact, researchers have found intent to leave or stay as the strongest predictor of actual turnover (Hendrix, Robbins, \& Summers, 1999, Lee \& Liu, 2007).

Review on the antecedent of turnover intentions have highlighted intent to leave rather than actual turnover as the outcome variable. Also results on the study of the relationship between turnover intentions and actual turnover have given support and evidence on the significant relationship between these variables (Lambert et al, 2001 in Nwosu, 2010). Literature has identified that work related factors, personal characteristics and external factors are good predictors of employee turnover tendency (Des \& Shawn, 2001, Oparah \& Faloye, 2007). 
Empirical studies have shown that turnover intentions are function of several variables that are satisfaction, motivation, organizational support, financial reward, communication promotion prospect and leadership styles (Alarape \& Akinlabi, 2003; Brown, 2003; Salami Omole, 2005). However, less study has focused on the effect or impact of turnover intentions on employees' effectiveness.

Organizational commitment is a very important construct for any organization to succeed. And the employee commitment is seen as the key factor in achieving competitive performance (Sahnawaz \& Juyal, 2006). Meyer \& Herscovitch (2001) defined commitment as a force that binds an individual to a course of action that is of relevance to a particular target. When employees as noted by Okpara (2004), Warsi, Noor, and Shidzada (2009) are sure that they will grow and learn with their current employers their level of commitment to stay with that particular organization is higher. In order to make employees to improve their job efficiency, there is a great need for strong and effective human resource strategies. These strategies must enhance employees' commitment to their career and organization, reduce turnover intentions and make organizational politics favourable to all employees.

Today however, an employee's non-commitment and turnover intention is a direct cost in the form of having to select, recruit and train a new employee (Dalton et al., 1992; Oparah \& Faloye, 2007). The existence of employees and non-commitment also has direct cost implications that include reduced morale, pressure on the remaining staff, and cost of learning and less cost of social capital (Dess \& Shaw, 2001). Employees' commitment, low turnover and positive organizational climate can have great positive effect on organizational productivity through employees' efficiency and efficacy. It can also disrupt group socialization process and increase the propensity of internal conflict, which was once noted by North, Rasmussen, Hughes and Finalyson (2005) to triggering additional turnover and non-commitment.

Demographic factor is another factor considered by the present study. Although demographic variables has been called to question in recent times. In spite of this, demographic background permits inferences and explanation as well as consequent policy decisions affecting subjects (Osiki, 1999). In line with this position, biographical variables could be seen as socio-personal, educational and occupational biodata. Essentially, they are vital information about a person's previous and present social, personal educational and career history (Adeyemo \& Aremu, 1999).

Despite of several empirical studies among organizational scholars, previous empirical findings are still less encouraging and have been inconclusive. This is especially in terms of the nature of the relationships and contributions of some organizational structure and performance on employees' efficiency and effectiveness. In relation to this, further investigations are required to determine the combined and differential contributions of some organizational factors (politics, turnover and commitment) on employees' efficiency and effectiveness. Most studies have focused on employees in product producing industries (see Chen \& Chen, 2008; Des \& Shaw, 2001; Lee \& Liu, 2007; 2002; Salami, 2008). This study therefore, investigated the predictive roles of organizational politics, turnover intentions and organizational commitment on employees' effectiveness and efficiency in academia.

\section{Research Hypotheses}

To achieve the purpose of this study, the following hypotheses were raised and tested at the 0.05 level of significance:

(1) Demographic factors (gender, educational level, work designation, marital status and work experience) will not significantly predict employees' work efficiency and effectiveness in academia. 
(2) Organizational politics, turnover intention and organizational commitment cannot combine to predict employees' efficiency and effectiveness in academia.

(3) Organizational politics, turnover intention and organizational commitment cannot relatively predict employees' work efficiency and effectiveness in academia.

\section{Methodology}

\section{Design of the Study}

This study adopted expost-facto research design. This is because the researcher is only interested in the determining the extent at which the predictor variables could determine the criterion variable and thus not have any intention of manipulating any of the predictor variables.

\section{Sample of Study}

The sample for this study consisted of 200 staff of Babcock University cutting across academic and administrative staff. The sample was drawn from four (4) faculties, and main administrative block and the registry. One hundred and twenty academic staff was randomly selected from the various faculties while eighty randomly selected non-academic staff participated in the study.

\section{Instrumentation}

The following three already validated instruments and the respondents' annual performance evaluation report were adopted for this study.

\section{Organizational politics}

Organizational politics were measured using Kacmar and Carlson's (1994) "Perceptions of Organizational Politics Scale (POPS)" POPS was defined as the degree to which the respondents view their work environment as political, and therefore unjust and unfair. The measure contain 12 parsimonious items measured on a five point despondence scale from 1 (strongly disagree) to 5 (strongly agree). A higher score meant a stronger perception of organizational politics. Sample items were "favoritism rather than merit determines who gets ahead around here", "there is a group of people in my department who always get things their way because no one wants to challenge them". POPS has been by many research are and has reliability coefficient of.76 (Parker et al, 1995); .77 (Vigodo, 2000), and .83 (Vigoda - Gadot, 2006).

\section{Organizational commitment}

Organizational commitment was measure using Meyer and Allen's (1991) instrument. The instruments consist of 24 items and were designed to capture three dimensions of organization comment namely effective, continuance, and normative. Each of the dimension of commitment is measured by ranging from strongly disagree (1) to strongly agree (5). The internal consisting measured by Cronbach's alpha for overall organizational commitment scale is 0.89 (Abdullah et al., 2005).

\section{Turnover intentions}

The turnover intentions were measured using O Driscoll and Benhr's (1994) turnover intention scale. The present job compare with an alternative that they may be interested in or able to obtain. The measure contain three items "Thought about quitting my job cross my mind" measured on a six point response scale from not at all to all the time. I plan to look for a new job within the next 12 months" measured on six point scale from strongly disagree to strongly agree; and, "how 
likely is it that, over the years, you will actively look for a new job outside this firm" measures on a six point response scale ranging from very unlikely to very likely. The relative co-efficient of turnover intention is 0.91 .

\section{Employees' efficiency and effectiveness}

This was measured using the secondary data of employees' annual performance evaluation reports in the registry of the University. This report measured indices of work records such as quality of work, resourcefulness/creativity/originality /discreteness, punctuality / absenteeism / participation at staff meetings and relationship with staff and significant others.

\section{Procedure}

Employees were met at their duty post after due permission was taken from their heads of departments. Participants were informed on the objective of the study and advised to be truthful in filling out the questionnaire. They are requested to supply their identity and department to allow for easy tracking of their evaluation reports. Two field research assistants helped in the distribution and collection of the questionnaires. Performance evaluation reports were later got from the registry and the total score of each employee as recorded in the performance evaluation questionnaire was later coded and analyzed along with the responses of each of them to the items of the questionnaire on organizational politics, commitment and turnover intention. Analysis was carried out using product moment correlation and hierarchical multiple regression analysis.

\section{Results}

Table 1: Correlation Matrix (Pearson's) and reliability (Cronbach's $\alpha$ ) for the research variables (in brackets).

\begin{tabular}{|l|l|l|l|l|l|l|}
\hline Variable & Mean & SD & $\mathbf{1}$ & $\mathbf{2}$ & $\mathbf{3}$ & $\mathbf{4}$ \\
\hline Orgl. Politics & 2.49 & 0.63 & $(0.79)$ & - & - & - \\
\hline Turnover Intention & 1.98 & 0.75 & $0.83^{* *}$ & $\left(0.81 \_\right.$ & - & - \\
\hline Orgl. Commitment & 2.11 & 0.70 & $-0.69^{* *}$ & $-0.73^{* *}$ & $(.0 .87)$ & - \\
\hline Work Efficiency & 3.07 & 0.81 & $-0.69^{* *}$ & $-0.81^{* *}$ & $0.93^{* *}$ & $(0.77)$ \\
\hline
\end{tabular}

Notes: $\mathrm{N}=200,{ }^{* *} \mathrm{P}<005$

Table 1 provides the description statistics and also demonstrates the psychometric properties of the variables of the study. The correlations between the research variables are in the expected direction. Convergent and high correlations was found between organizational politics and turnover intentions $(\mathrm{r}=.83 ; \mathrm{p}<.08)$, work efficiency and organizational commitment $(\mathrm{r}=.93 ; \mathrm{p}<.05)$. On the other hand divergent and high correlation was observed between organizational politics and organizational commitment $(r=.69 ; \mathrm{p}<.05)$; organizational politics and work efficiency $(\mathrm{r}=$ $.69, \mathrm{p}<.05)$; organizational commitment and turnover intention $(\mathrm{r}=-.73, \mathrm{p}<.05)$ work efficiency and turnover intentions $(\mathrm{r}=.81, \mathrm{p}<.05)$. 
Table 2: Analysis of the composite effect of predictor variables on job efficiency

\begin{tabular}{|c|c|c|c|c|c|c|}
\hline $\begin{array}{l}\text { R } \\
\text { R2 } \\
\text { Adj. } \mathbf{R}^{2} \\
\text { SE }\end{array}$ & $\begin{array}{ll}= & .441^{\mathrm{a}} \\
= & .218 \\
= & .103 \\
= & \mathbf{1 5 . 0 1 9}\end{array}$ & & & & & \\
\hline Model & & Sum of Square & Df & Means of Square & $\mathrm{F}$ & Sig \\
\hline \multirow[t]{2}{*}{ Regression } & & 1462.721 & 3 & 487.574 & & \\
\hline & & & & & 10.504 & .000 \\
\hline Residual & & 9098.124 & 196 & 46.419 & & \\
\hline Total & & 10560.845 & 199 & 46.419 & & \\
\hline
\end{tabular}

$\mathrm{P}<.05$ level

From Table 2, it could be seen that the regression value for the combined effect (.441) and the adjusted $\mathrm{R}^{2}(.103)$. This implies that $10.3 \%$ of the variance in the employees' job efficiency is accounted for by the predictor variables. It could also be seen from the table that the F-value of 10.504 is significant at less that 0.05 alpha level. This shows that the predictor variables (organizational politics, turnover intention, and organizational commitment) have significant effect on the criterion variable (employees' job efficiency). Thus, the hypothesis which stated that organizational politics, turnover intention and organizational commitment cannot combine to predict employees' work efficiency in academia is rejected while the alternative hypothesis is sustained.

Table 3: A four hierarchical regression analyses of work efficiency on demographic factors, organizational justice, turnover intention and organizational commitment.

\begin{tabular}{|l|l|l|l|l|l|l|l|}
\hline Variables & $\mathbf{R}$ & $\mathbf{R}^{\mathbf{2}}$ & $\mathbf{\Delta \mathbf { R } ^ { 2 }}$ & $\mathbf{\Delta} \mathbf{F}$ & $\boldsymbol{\beta}$ & $\mathbf{D f}$ & $\mathbf{T}$ \\
\hline Step 1 & & & & & & & \\
\hline Demographic Factors & .19 & .07 & .03 & $4.02^{*}$ & & 5,184 & \\
\hline Gender & & & & & .17 & & $2.79^{*}$ \\
\hline Marital Status & & & & & .17 & & $2.86^{*}$ \\
\hline Work Designation & & & & & .29 & & $5.33^{*}$ \\
\hline Educational Status & & & & & .21 & & $4.07^{*}$ \\
\hline Work Experience & & & & & .26 & & $4.91^{*}$ \\
\hline Step 2 & & & & & & & \\
\hline Organizational Politics & .44 & .19 & .15 & $4.76^{*}$ & .24 & 6,193 & $5.05^{*}$ \\
\hline Step 3 & & & & & & & \\
\hline Turnover Intention & .36 & .10 & .10 & 3.00 & .15 & 7,192 & $2.63^{*}$ \\
\hline Step 4 & & & & & & & \\
\hline Orgl. Commitment & .42 & .13 & .11 & $4.53^{*}$ & .21 & 8,191 & $4.88^{*}$ \\
\hline
\end{tabular}

$* \mathrm{P}<.05$ (2-tailed test)

a. Gender was scored $1=$ male, $2=$ female

b. Marital status was scored $0=$ single, $1=$ married

c. Work designation was scored $1=$ academic staff, $2=$ non-academic

d. Highest educational status was scored $5=\mathrm{PhD}, 4=$ masters, $3=$ bachelor degree, $2=$ $\mathrm{HND}, 1$ = NCE/ OND

e. Work experienced was scored $1=0$-5years, $2=6$-10years, $3=11$-20years, $4=21$ years +

Table 3 shows the regressed results of the demographic variables (step 1) as well as the relative contribution of the predictor variables on the criterion variable (step 2, 3 and 4). Hypothesis one 
that postulated that demographic factors will not significantly predict employees work efficiency is rejected based on the outcome of the findings $\left(\Delta \mathrm{R}^{2}=.03, \mathrm{df}(5,194)=4.02, \mathrm{P}<.05\right)$. Therefore gender, marital status, work designations, educational status and work experience made significant separate contributions to the prediction of employees' efficiency in academia. Work designation is the most potent factors $(\beta=.29)$, followed by work experience $(\beta=.26)$; educational status $(\beta=.21)$, lastly by gender and marital status with beta value of .17 respectively.

Step 2, 3 and 4 on Table 3 shows the relative contribution of each of the predictor variables to the variance in employees' efficiency in academia. Organizational politics has the highest beta value (5.05), followed by organizational commitment (4.88) and lastly by turnover intentions (2.63), all significant at 0.05 alpha level. Therefore, organizational politics predicts employees' efficiency most in academia, followed by organizational commitment and lastly by turnover intention. It could be deduced that organizational justice, turnover intention and organizational commitment relatively predict employees' work efficiency in academia.

\section{Discussion}

The results of this study on the relationship among the variable of this study show some interesting evidence. High and positive correlation was found between organizational politics (OP) and turnover intention (TI) ( $\mathrm{r}=.83$ ), also with work efficiency (WE) and organizational commitment $(\mathrm{OC})(\mathrm{r}=.93)$. Negative and high correlation was seen in the relationship between organizational politics, work efficiency and commitment, as well as organizational commitment, turnover intention and work efficiency. The implication of this is that work behaviour and organizational success are related, and the environment in which one work is very crucial to organizational behaviour and success.

Glisson and James (2002) affirmed that organizational environment is as a reflection of workers' perception of and emotional response to characteristic of their work. Again, when viewed against the submission of Morris and Bloom (2002) that work attitude could mediate the effect of organizational climate on employees' performance (efficiency and effectiveness) and motivation and organizational characteristic influence employees' commitment to their organizational and their job.

This study also revealed that the independent variables (organizational politics, turnover intention and organizational commitment) were significant predictors of employees' work efficiency and effectiveness in academia. The study further found that organizational politics and commitment are the most potent factors and lastly by turnover intention. Result from this study corroborates earlier studies of Des and Shaw (2001); Oparah and Faloye (2007), Warsi, Noor and Sahibzada (2009), North et al, (2005) that employees' non-commitment, intention to leave or stay and organizational politics can have adverse and negative effect on organizational productivity through employees' efficiency and efficacy.

The study also confirmed that organizational politics as the most potent predictor of efficiency in this study can disrupt group socialization process and increase the propensity of internal conflict which was once noted by North at el (2005) to triggering additional turnover and noncommitment.

While considering the direction of the significant of this study based on demographic factors, tables 3 revealed that gender, marital status, work designation educational status, and work experience made significant separate contributions to the prediction of employees' efficiency and effectiveness. This result lends a good credence from Dodd-McCue and Wright (1996) and Salami (2008) on the roles played by demographic variables in determining organizational behavior and success. 


\section{Conclusion}

With the findings of this study it could be concluded that organizational politics, turnover intentions and organizational commitment would predict employees' effectiveness and efficiency in academia. Organizational politics and commitment are however the most powerful factors in employees' efficiency and effectiveness in academia.

Consequent upon the findings of this study, it is recommended that the management of schools in higher citadel of learning be it private or public should pay a great attention to employees' commitment in order to achieve increased productivity and retain best hands. This could be achieved by providing adequate support through HRM practices, reduce favoritism to the bearest minimum and create enabling and conductive environment for employees to discharge their duties. Thus, a happy employee is a better employee.

\section{References}

Adams, G. L., Ammeter, A. P., Treadway, D. C., Ferris, G. R., Hochwarter, W. A., \& Kolodinsky, R.W. (2002). Perceptions of organizational politics: Additional thoughts, reactions, and multi-level issues. Research in Multi-Level Issues, 1, 287-294.

Adeyemo, D. A., \& Aremu, A. O. (1999). Career commitment among secondary school teachers in Oyo State: The role of biographical moderators. Nigeria Journal of Applied Psychology, 5(2), 185-195.

Ajzen, I. (1991). The theory of planned of the behaviour. Organizational Behaviour and Human Decision Process, 50, 179-211.

Alapere, A. I., \& Akinlabi, F. M. (2000). Influence of perceived organizational supports and discretionally treatment on work attitude of industrial worker. African Journal for the Psychology Study of Social Issues, 5(1), 23-36.

Allen, N. J., \& Meyer, J. P. (1990). The measurement and antecedents of affective, continuance, and normative commitment to the organization. Journal of Occupational Psychology, 63, 1-18.

Andrews, M. C., \& Kacmar, K.M. (2001). Discriminating among organizational politics, justice, and support. Journal of Organizational Behavior, 22, 347-366.

Brown, B. B. (2003). Employees' organizational commitment and tier perception of supervisors' relations oriented and task-oriented leadership behaviour. Ph.D dissertation of Virginia Polytechnic Institute.

Chen, S., \& Chen, L (2008). A case study of contract workers and turnover intentions in Taiwan. Retrieved from http://www.findarticle.com

Cropanzano, R. S., \& Kacmar, K. M. (1995). Organizational politics, justice, and support: Managing the social climate of the workplace. Westport, CT: Quorum Books.

Dess, G. D. \& Shaw, J. D. (2001). Voluntary turnover, social capital and organizational performance. Academy of Management Review, 26(3), 466-454.

Dodd-McCue, D. \& Wright, G. B. (1996). Men, women and attitudinal commitment: The effects of workplace experience and socialization. Human Relations, 49, 1065-1089.

Dipboye, R. L., \& Foster, J. B. (2002). Multi-level theorizing about perceptions of organizational politics. Research in Multi-Level Issues, 1, 255-270.

Ferris, G. R., \& Kacmar, K. M. (1992). Perceptions of organizational politics. Journal of Management,18, 93-116.

Ferris, G. R., Russ, G. S., \& Fandt, P. M. (1989). Politics in organizations. In R. A. Giacalone \& P. Rosenfeld (Eds.), Impression management in the organization (pp. 143-170). Hillsdale, NJ: Erlbaum.

Hendrix, W. H., Robbins, T. \& Summers, T. P. (1999). Effect of procedural and distribution justice on factor predictor of turnover. Journals of Social Behavior and Personality, 13(4), 611-632. 
Kacmar, K. M., \& Baron, R. A. (1999). Organizational politics: The state of the field, links to related processes, and an agenda for future research. Research in Personnel and Human Resources Management, 17, 1-39.

Kipnis, D., Schmidt, S. M., \& Wilkinson, I. (1980). Intraorganizational influence tactics: Exploration in getting one's way. Journal of Applied Psychology, 65, 440-452.

Lee, C. Y., \& Liu, C. U. (2007). An examination of factors affecting repatriates turnover intentions. International Journal of Manpower, 28(2), 122-134.

Meyer, J. P., Stanley, D. J., Herscovitch, L., \& Topolnytsky, L. (2002). Affective, continuance, and normative commitment to the organization: A meta-analysis of antecedent, correlates, and consequence. Journal of Vocational Behaviour, 61(1), 20-52.

O’Connor, W. E., \& Morrison, T. G. (2001). A comparison of situational and dispositional predictors of perceptions of organizational politics. The Journal of Psychology, 135, 301-312.

Ogunyemi, A. O (2007). Perceived leadership style, motivation and training as predictors of workers' productivity in a manufacturing industry in Lagos State, Nigeria. Ogun Journal of Counseling Studies, 1(1), 76-83.

Okpara, J. O (2004). Job satisfaction and organizational commitment: Are there differences between American and Nigeria managers employed in the US MNCs in Nigeria? Academy of Business and Administrative Science, Briarcliffes College Switzerland.

Oparah, O. B., \& Faloye, J. O. (2007). Influence of occupational stress ad organizational politics on turnover intention among selected industrial workers in Ibadan. Ogun Journal of Counseling, 1(1), 9-16.

North, N., Rasmusson, E., Hughes, F., \& Finlayson, M. (2005). Turnover amongst nurses in New Zealand district health boards: A national survey of nursing turnover and turnover cost. Journal of Employment Relation, 30-49

Pfeffer, J. (1992), Management with power. Boston, MA: Harvard Business School Press.

Sahnawaz, M. G., \& Juyal, R. C. (2006). Human resources management practices and organizational commitment in different organizations. Journal of the Indian Academy of Applied Psychology, 32, 171178.

Salami, S. O., \& Omole, O. A. (2005). Participation in decision making process, incentives and training as predictors of organizational commitment among industrial workers. African Journal for the Psychological Study of Social Issues.

Salami, S. O. (2008). Demographic and psychological predicting organizational commitment among industrial workers. Anthropologist, 10(1), 31-38.

Valle, M., \& Perrewe', P. L. (2000). Do politics perceptions relate to political behaviors? Tests of an implicit assumption and expanded model. Human Relations, 53, 359-386.

Vigoda-Gadot, E. (2003). Developments in organizational politics. Cheltenham: Edward Elgar Publishing.

Vigoda-Gadot, E. (2006). Leadership style, organizational politics, and employees' performance: An empirical examination of two competing models. Retrieved from www.emeraldinsight.com/0048$\underline{3486 . h t m}$

Warsi, S. I., Noor, F., \& Sahibzada, S. (2009). Study on relationship between organizational commitment and its determined among private section employees of Pakistan. International Review of Business Research Papers, 5(3), 399-410. 


\section{Biographies}

Lasun Gbadamosi PhD is a Professor of Human Resources, Planning and Management. He is currently the Dean of Faculty of Education, Olabisi Onabanjo University, Ago-iwoye, Ogun State, Nigeria.

Nwosu Jonathan Chinaka is a $\mathrm{PhD}$ candidate of Educational Management of Faculty of Education, Olabisi Onabanjo University, Ago-iwoye, Ogun State, Nigeria. Presently, he is the Deputy Registrar of Babcock University Ilishan, Ogun State, Nigeria. 